\title{
教室でのタブレット端末利用における課題と児童の疲労に関する 調查1
}

柴田隆史 ${ }^{2}$, 佐藤和紀 ${ }^{3}$, 堀田龍也 ${ }^{4}$

\begin{abstract}
Along with the education informatization, use of tablet computers in school classrooms is gaining considerable popularity as a means of improving educational quality. Accordingly, investigating the tablet computer usage among students from an ergonomics viewpoint is important because the usage environment in schools differs from that in daily life. For example, in the classroom, students use tablet computers in their own seats that exist in a bright indoor environment. This study focuses on how elementary school students face difficulties and if they experience fatigue while using tablet computers. This study aims to understand the current situation of elementary school students using tablet computers. A total of 830 elementary school students, including first to sixth graders, who used tablet computers in classrooms for over a year responded to the survey. The results revealed that $57 \%$ of the elementary school students faced difficulty while looking at a tablet screen because of its glare. Moreover, approximately one out of every three students experienced physical fatigue from using a tablet computer, with the most common symptoms being visual fatigue and neck and shoulder pains. Therefore, the results suggest the necessity to take measures that enable students to use tablet computers without difficulty to achieve the purpose of building a learning environment using the information and communication technology.
\end{abstract}

教育の情報化に伴い，学校の教室でタブレット端末を利用する機会が増えている．教室でのタブレッ 卜端末の利用は，明るい室内環境の中で決められた自分の座席で用いるなどと日常生活での利用とは異 なるため，学校での児童の利用について人間工学的視点により検討することは重要である. そこで本研 究では，小学校でのタブレット端末利用における，児童が抱えるユーザビリティの問題と身体疲労に着 目した検討を行った．本研究の目的は，児童のタブレット端末利用の実態を明らかにすることであり， そのために，小学校でタブレット端末を 1 年以上使用した小学 1 年から 6 年までの児童 830 名を対象として, タブレット端末の使いやすさと児童の身体的側面への影響に関するアンケート調查を実施した. その結果， 児童の約 $57 \%$ がタブレット端末の画面に蛍光灯が映りこんで見にくいと感じていることや，3人に 1 人の 児童が眼や首，肩などに身体疲労を感じていることが明らかになった。それにより，ICTを活用した学 習環境の構築のためには，児童がタブレット端末を無理なく使える対策を講じる必要性が示唆された.

(キーワード：ICT，タブレット端末，疲労，小学生，子ども)

\section{1.はじめに}

学校ではICT (Information and Communication Technology）を活用した教育の情報化が推進され，先進 的な学校では，すでに児童生徒1人1台のタブレット端末

1 受付：2019年2月6日 受理：2019年8月20日

2 東京福祉大学教育学部

School of Education, Tokyo University of Social Welfare

3 常葉大学教育学部

Faculty of Education, Tokoha University

4 東北大学大学院情報科学研究科

Graduated School of Information Sciences, Tohoku University
や，教室での電子黒板やプロジェクターによる大型提示 装置などのICT学習環境が整えられている，例えば，文 部科学省が 2018 年 10 月に公表した「平成 29 年度学校に おける教育の情報化の実態等に関する調査 (調査基準日： 2018年3月1日現在)」でも，電子黒板やタブレット型コ ンピュータなどのICT機器の整備台数は年々増加してい ることが示されている11. その調査結果によると，現在， 全国の公立学校では，タブレット端末などの教育用コン ピュータ 1 台を児童生徒が 5.6 人で使える程度にまで普及 している状況である。ただし，これはあくまでも割合で あり，学校での児童生徒のタブレット端末の利用を考え た場合，1人が 1 台のタブレット端末を利用することが望 
ましく，現在の実際の利用においても，1人で1台を使う ことが多いことを補足しておく，さらに，その調査からは， 教員のICT活用指導力が年々向上していることも報告さ れており，学校に打ける教育の情報化が進んでいること が示されている.

学校教育の情報化の推進と普及を背景として，2018年 5月には，学校教育法の一部が改正され，2019年4月より， 紙の教科書の代わりにデジタル教科書が使用できるよう になった，そのため今後は，今よりも多くの小学校や中 学校, 高校などにおいて, 学習者用デジタル教科書やデ ジタル教材が活用されていくことが予想され，さらに多 くの児童生徒がICT機器を利用していくと推測される.

児童生徒が学校で利用する機会が多いICT機器はタブ レット端末であるため, 本研究ではICT機器の中でも特 にタブレット端末に着目した。また本稿では，上記の文 部科学省によるタブレット型コンピュータと同じ定義1) を用いて，平板状の外形を備えタッチパネル式などの表 示/入力部を持った教育用コンピュータのことを総称し てタブレット端末と表すことにする.

\section{2. 学校でのタブレット端末利用と研究の目的}

学校での学習におけるタブレット端末の活用は，デジ タル教科書・教材を見る, カメラ機能で撮影する, 罒や 絵を描く, 文字を書く,グループワークで考えをまとめる， 意見を共有するなどと様々であり，ICTにより教育を支 援し，学習効果を高めることが期待されている22.

ICTといったテクノロジーの活用や製品の開発におい ては，使いやすさや人に与える影響を評価して，安全で 快適な環境について検討することが必要である，学校で のICT機器利用については，文部科学省より「児童生徒 の健康に留意してICTを活用するためのガイドブック3)」 が発行されている。しかし，その活用や効果などについ ては検討が十分になされていなく，人間工学的視点を取 り入れた調査や詳細な検討が必要とされる. また，児童 生徒による学校でのICT機器利用について, 学校現場で は健康面への影響などが懸念されているのにも拘わらず， 状況や課題を把握して対策を考えていく根拠となる調査 データや知見はほとんどない，さらに，学校で導入され ているタブレット端末は，成人が使うことを想定して設 計されていることも多く，児童生徒が用いる場合には何 か対応が必要となることも考えられる，あるいは，児童 生徒が学習で用いるためのタブレット端末を開発する必 要があるかもしれないが，その必要性さえも調査されて いないのが現状である.
以上のことをふまえ，安全で快適に教育効果を高める ICT学習環境を実現するためには，教室でタブレット端 末を用いることの課題や状況を，児童生徒の利用実態に 基づいて明確にし，適切な対策や解決を図っていくこと が必要である，そこで本研究では，教室での児童のタブ レット端末利用の実態を明らかにすることを目的とし， 教室でのタブレット端末利用における使いやすさや身体 疲労に関するアンケート調査を実施した。

\section{3. 調查方法}

\section{3-1. 調査対象}

アンケート調查は，国内の公立小学校9校に対して行 い, 学校の授業でタブレット端末を 1 年以上使用している 児童830名が対象であった。1年生は 40 名，2年生は 33 名, 3 年生は 54 名， 4 年生は 134 名，5年生は 222 名，6年生は 347名であった。なお，調査対象校の選定と調查は，以 下の手続きにより，倫理的な配慮を行ったうえで実施し た。まず事前に，複数の小学校へ文書により，児童に対 してアンケートを行うことや調査の目的，回答により個 人が特定されることはないことや調査結果は研究のため のみに使われることなどのデータの取り扱いを伝えて, 調査協力の依頼をした，そして，当該校の管理職の判断 によりインフォームド・コンセントを得られた学校を調 査対象校とした。 また，調査対象校での調査実施におけ る児童及び保護者への了解等の対応については，当該校 の取り決めに準じて許諾を得ることができた児童のデー タを分析の対象とした。

児童によるアンケート用紙への記入は，各小学校の教 員の指示により，クラスごとに行われ，児童は調査に関 する説明を受けた後，普段の授業でのタブレット端末利 用について回答した。調査時期は 2016 年3月であり，年 度末に調查を実施した。そのため，調査対象となった 1 年生も 1 年間のタブレット端末の利用経験があった。 な お，一般に，学校で用いるタブレット端末は学校や自 治体により異なっており，本研究の調查対象となった 9校でも異なるタブレット端末を用いていた。 また，授 業に打けるタブレット端末の使用頻度や時間も，学習内 容や学習場面に依存するため, 学校により異なっていた.

\section{3-2. 調査内容}

アンケートでは，学年や年齢，性別，何年生から学校 でタブレット端末を使っていたかなどの属性の他，タブ レット端末の使いやすさと身体疲労に関わる，以下の 
16項目の設問について質問した.

\section{1）タブレット端末での学習の得意さに関する設問}

タブレット端末を使って学習することが得意であると 思うか，「あてはまらない，「あまりあてはまらない」，「少し あてはまる」，「あてはまる」の4件法でたずねた (設問1).

\section{2) タブレット端末の使いやすさに関する設問}

画面への映り込みについて，次の4つの質問をした． 設問は，「画面に蛍光灯が映りこんで，見にくいことが ある(設問2)」，「画面に蛍光灯が映りこむことを知って いましたか? (設問3)」，「タブレット端末を傾けて使う ことがある (設問4)」,「タブレット端末を傾けて使った ことがある場合は，その理由を教えて下さい（設問5)」 であった，穴の際，設問2と4については，「ない」，「あ まりない」，「ときどきある」「よくある」の4件法でたず ねた，設問3については，「はい」か「いいえ」で回答さ せたそそして，設問5については，複数回答を許可した 上で, 以下の $4 つ の$ 選択肢と,「その他」という自由記述 欄を設けた，選択肢は，「蛍光灯などの映りこみをなく すため」，「画面を正面から見ることで文字や写真などを 見やすくするため」，「画面をタッチしやすくするため」， 「紙の教科書も傾けるため」であった.

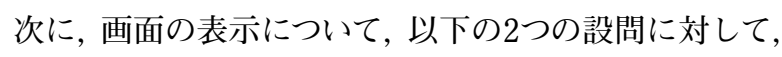

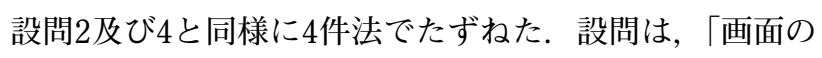
文字が小さくて見にくいので，表示を大きくしたことが ある（設問6)」，「画面の明るさを自分で調整することが ある（設問7）」であった。

さらに, 絵や文字の入力について, 以下の 4 つ設問 に対して，同じく4件法でたずねた，設問は，「絵や文 字を自由に書くときに，指を使うことがある(設問8)」, 「絵や文字を自由に書くときに，タブレットペンを使う ことがある (設問9)」，「指やペンを使って，画面の思っ た通りの場所に絵や文字が書けずに，ずれてしまうこと がある（設問10）」，「指やペンで文字が書きにくいと思 うことがある（設問11）」であった。

その後, タブレット端末を使っていて，困っているこ とや使いづらいことがある場合には自由記述を求めた (設 問12).

\section{3）身体疲労に関する設問}

次の3つの設問に対して，「あてはまらない」「あまり あてはまらない」，「少しあてはまる」，「あてはまる」の 4件法でたずねた. 設問は,「タブレット端末を使うときは, 紙の教科書を使うときよりも目を近づけていると思う（設 問13)」，「タブレット端末を使うときの方が，紙の教科 書を使うときよりも目がつかれると思う (設問14)」,「タ ブレット端末を使っていて, 腕や肩などの体のつかれを

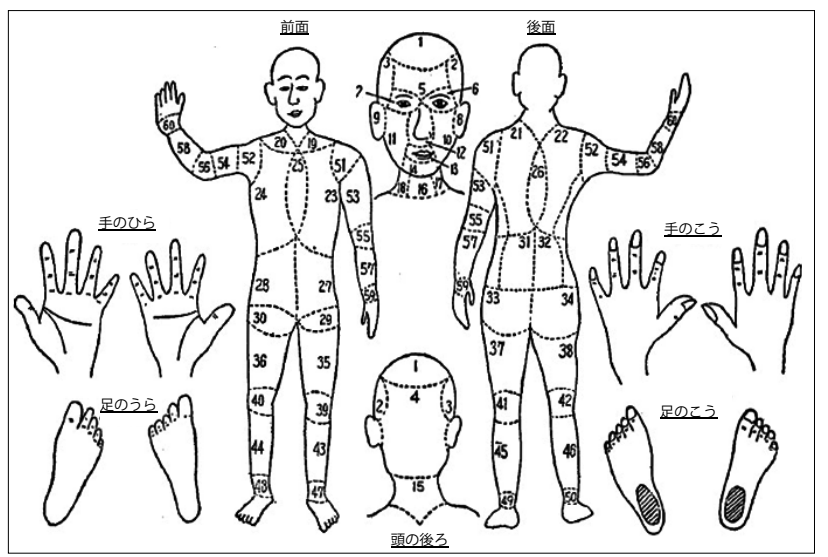

図1 アンケートの設問16に扔いて疲労部位に印を付けるた めの図4)

Fig. 1 Illustration for marking fatigue parts in Question 16 of the questionnaire ${ }^{4)}$.

感じることがある (設問15)」であった，さらに，設問 15で「あてはまらない」以外に○を付けた人に対して， アンケート用紙に描かれた図において (図1), タブレッ 卜端末を使った学習で，疲れ，こり，痛み，だるさ等が あった部位に○印を付けさせた（設問16）。なお，図1は 日本産業衛生学会・産業疲労研究会による身体疲労部位 調査票4)で用いられている図を小学生に分かりやすいよ うに改変したものであり, 複数回答を許可した.

\section{3-3. 分析}

児童による回答の傾向を明確にすることを目的として， 4 件法で回答させた設問 $1 ， 2 ， 4$ と 6 11，13〜15につい ては，「あてはまらない」と「あまりあてはまらない」及 び「ない」と「あまりない」を，それぞれ設問に対して否 定する回答，そして，「少しあてはまる」と「あてはまる」 及び「ときどきある」と「よくある」を，それぞれ設問に 対して肯定する回答と分類して，二項検定を行った．さ らに，どのような要因が身体疲労に関連するのかを検討 するために，因子分析を行った上で重回帰分析を行った.

\section{4. 結 果}

アンケートの設問ごとに結果を示す. グラフ内の数值 は，全体に対する回答数の割合を示す.

\section{4-1. タブレット端末での学習の得意さ}

調査対象であった児童の約 $82 \%$ ， タブレット端末を 使って学習するのは得意であると回答した (図2)。二項 検定の結果, 有意差が認められた $(n=826, p<0.01)$. 
設問1. タブレット端末を使って学習するのは得意である.

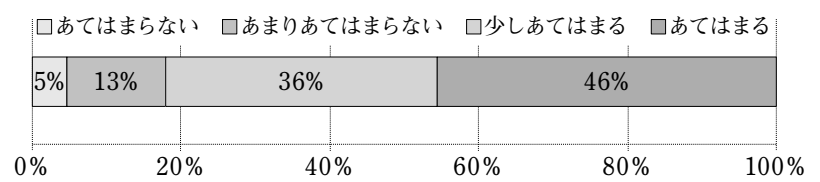

図2 タブレット端末を使った学習の得意さに関する結果（設 問1)

Fig. 2 Result on a degree of excellence in learning using a tablet (Question 1).

設問2. 画面に蛍光灯が映りこんで，見にくいことがある. ロない ロあまりない ロときどきある ロよくある

\begin{tabular}{|l|l|l|l|l|l|}
\hline $16 \%$ & $27 \%$ & \multicolumn{2}{|c|}{$44 \%$} & $13 \%$ \\
\hline & & & & & \\
\hline $0 \%$ & $20 \%$ & $40 \%$ & $60 \%$ & $80 \%$ & $100 \%$ \\
\hline
\end{tabular}

設問3．画面に蛍光灯が映りこむことを知っていましたか? ロはい ロいいえ

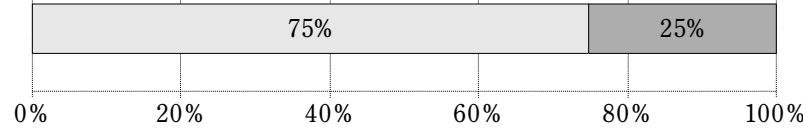

設問4. タブレット端末を傾けて使うことがある.

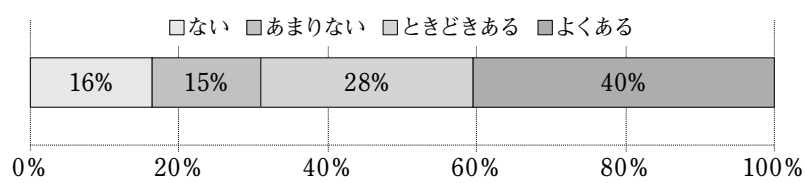

図3 タブレット端末の見やすさに関わる結果（設問2４）

Fig. 3 Results on tablet's visibility (Questions 2 to 4).

\section{4-2. タブレット端末の使いやすさ}

図3に，見やすさに関わる設問2から4の結果を示す. 設問 2 かは，約 $57 \%$ の児童が，画面に蛍光灯が映りこ んで見にくいと思うことが示された $(n=829, p<0.01)$. また，設問3から，約 $75 \%$ の児童が，タブレット端末の 画面に蛍光灯が映りこむことを知っていた $(n=788$, $p<0.01)$. 設問4より，タブレット端末を傾けて使った ことがある児童は，約 $69 \%$ であった $(n=820, p<0.01)$.

設問5ではタブレット端末を傾けて使った理由を質問 しており，その結果として，選択肢の中で一番回答が多 かったのは，「画面を正面から見ることで文字や写真な どを見やすくするため (338回答)」であった，以下，順 に「画面をタッチしやすくするため（290回答）」，「蛍光 灯などの映りこみをなくすため（176回答）」であり，「紙 の教科書も傾けるため (31回答)」は少数であった.また， 「その他」として自由記述された主な回答として，「画面 に文字を書きやすくするため」，「首が疲れないようにす
設問6. 画面の文字が小さくて見にくいので, 表示を大きくしたことがある.

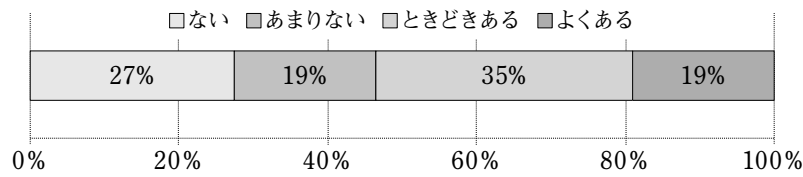

設問7．画面の明るさを自分で調整することがある.

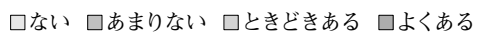

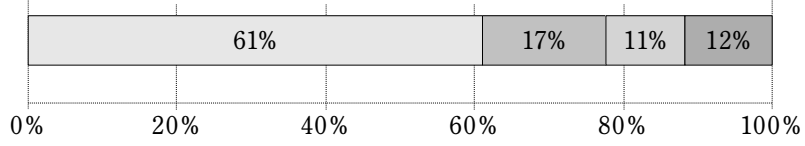

図4 タブレット端末の見やすさに関わる結果（設問6，7）

Fig. 4 Results on tablet's visibility (Questions $6 \& 7$ ).

設問8．絵や文字を自由に書くときに，指を使うことがある.

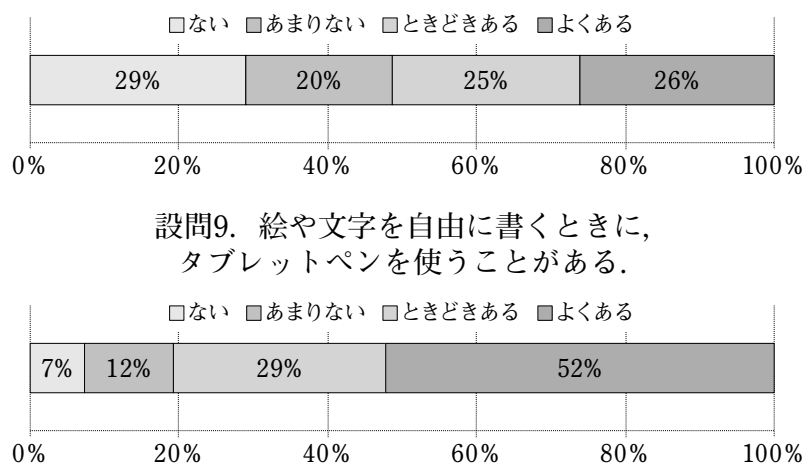

設問10. 指やペンを使って，画面の思った通りの場所に 絵や文字が書けずに，ずれてしまうことがある.

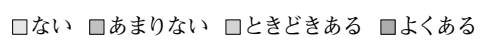

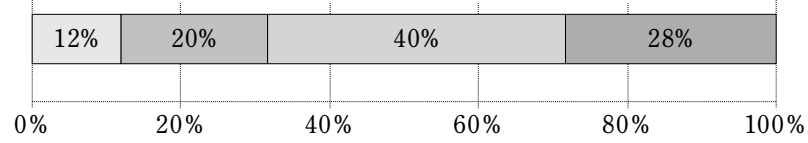

設問11. 指やペンで文字が書きにくいと思うことがある.

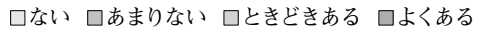

\begin{tabular}{|l|c|c|c|c|c|}
\hline \multicolumn{2}{|c|}{$21 \%$} & $22 \%$ & \multicolumn{2}{c|}{$33 \%$} & \multicolumn{2}{c|}{$24 \%$} \\
\hline & & & & & \\
\hline
\end{tabular}

図5 タブレット端末への入力に関わる結果（設問8～11)

Fig. 5 Results related to input to tablets (Questions 8 to 11).

るため」，「姿勢を良くするため」，「となりの人やみんな に発表するため」，「先生にそう言われたから」，「画面を 明るくするため」，「いつもゲームを傾けてするから」な どが挙げられた.

設問6の結果より，約 $54 \%$ の児童が，画面の文字が小 さくて見にくいので，表示を大きくする経験があること が示された $(n=826, p<0.05)($ 図4)。また，設問7より， 約 $61 \%$ の児童が，画面の明るさを自分で調整したことが 全くなかった，逆に，約 $22 \% の$ 児童が，明るさを自分で 
調整したことがあった $(n=825, p<0.01)$.

設問8より，絵や文字を自由に書くときに，指を使う ことがあった児童は約 $51 \%$ であり $(n=823, n . s$.$) ，設$ 問9より，タブレットペンを使うことがあった児童は約 $81 \%$ であった $(n=827, p<0.01)$ (困5)。また，設問 10 より，約 $68 \%$ の児童が，指やペンを使って，画面の思っ た通りの場所に絵や文字が書けずに，ずれてしまう経験 があることが示された $(n=826, p<0.01)$. さらに，設 問11より，約 $57 \%$ の児童が，指やペンで文字が書きにく いと思う経験があった $(n=825, p<0.01)$.

設問 12 ，タブレット端末の利用で困っていることや 使いづらいことに対して自由記述された回答は，主に， タブレット端末のシステムやソフトウェアに関係するこ と（例 :「反応しなくなる」，「フリーズすることがある」， 「違うボタンを押してしまう」など)，そして，絵や文字 が書きにくいこと（例：「思ったように文字が書けない」， 「字を書くのが不便」,「タッチしたところとずれることが ある」など)，及び，身体疲労に関すること（例：「ずっと 使っていると目が疲れる」，「頭痛がする」，「手が疲れる」 など)であった.

\section{4-3. 身体疲労}

設問 $13 よ り ，$ 約 $31 \%$ の児童が，タブレット端末を使う ときは，紙の教科書を使うときよりも目を近づけている と思っていた．ただし，多くの児童はそうではなかった

設問13. タブレット端末を使うときは, 紙の教科書を使うときよりも目を近づけていると思う。

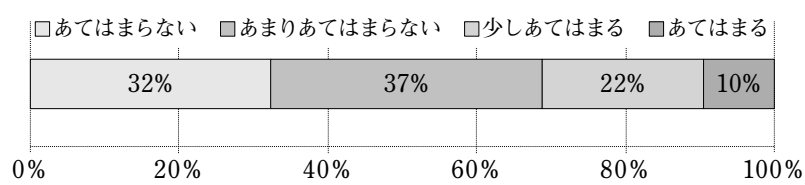

設問14. タブレット端末を使うときの方が, 紙の教科書を使うときよりも目がつかれると思う。

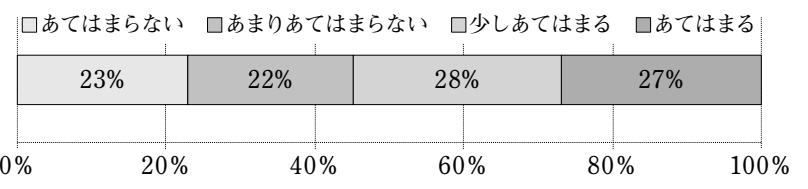

設問15. タブレット端末を使っていて, 腕や肩などの体のつかれを感じることがある. 口あてはまらない ロあまりあてはまらない ロ少しあてはまる ロあてはまる

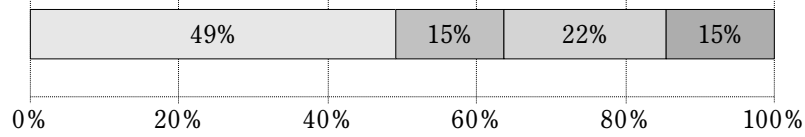

図6 タブレット端末利用における身体疲労に関わる結果（設 問13〜15)

Fig. 6 Results related to physical fatigue by using tablets (Questions 13 to 15 ). $(n=818 ， p<0.01)$ (図6)。また，設問14より， 約55\% の児童が，タブレット端末を使うときの方が，紙の教科 書を使うときよりも目が疲れると思っていた $(n=825$, $p<0.01)$ ．設問15からは，約 $36 \%$ の児童が，タブレット 端末を使っていて，腕や肩などの体の疲れを感じている ことが示された。 ただし，半数以上の児童はそうではな かった $(n=827, p<0.01)$.

\section{4-4. 身体疲労に関連する要因}

設問のどのような要因が身体疲労に関連しているのか を分析した. その際，小学 $1,2 ， 3$ 年生は調査対象となっ たクラスが少なく，担任教諭による指導など，特定の要 因が結果に強く影響を与えている可能性があったため, 4，5，6年生の結果を分析の対象とした.

設問 $1 ， 2 ， 4$ と6 11，13，14の11個の設問に対して 因子分析（主因子法，プロマックス回転）を行ったとこ ろ，4つの因子が抽出された. 各因子を構成する項目と その因子負荷量を表 1 に示す。第4因子までの累積寄与率 は34.15\%だった。

第1因子は，設問10と11が含まれた．文字の書きにく さに関する児童の認識から構成されており，「書くこと の不便さ」と解釈された．第2因子は，設問 $2 ， 6 ， 13$, 14が含まれた。眼の疲れや視距離，画面の見にくさに関 する児童の認識から構成されており，「見ることの不便 さ」と解釈された. 第3因子は, 項目 $1 ， 4 ， 7$ 含まれた. 画面の明るさ調整や傾斜させる工夫，タブレット端末を 使った学習の得意さに関する児童の認識から構成されて おり，「調整してうまく使うスキル」と解釈された．第4 因子は，指やペンで書く方法に関する児童の認識から構

表1 身体疲労に関連する項目に関する因子分析の結果

Tab. 1 Results on factor analysis on items related to physical fatigue.

\begin{tabular}{|c|c|c|c|c|}
\hline 項目 & $\begin{array}{c}\text { 書くことの } \\
\text { 不便さ }\end{array}$ & $\begin{array}{c}\text { 見ることの } \\
\text { 不便さ }\end{array}$ & $\begin{array}{c}\text { 調整してうまく } \\
\text { 使うスキル }\end{array}$ & $\begin{array}{c}\text { 画面に入力 } \\
\text { する方法 }\end{array}$ \\
\hline 設問10 & .941 & -.036 & -.077 & .016 \\
\hline 設問11 & .562 & .149 & -.003 & -.065 \\
\hline 設問14 & -.036 & .675 & .021 & -.074 \\
\hline 設問13 & .087 & .479 & -.005 & .008 \\
\hline 設問2 & .064 & .339 & .223 & -.087 \\
\hline 設問6 & .117 & .221 & .102 & .136 \\
\hline 設問7 & -.074 & .137 & .519 & .135 \\
\hline 設問1 & -.010 & -.286 & .408 & -.179 \\
\hline 設問4 & -.041 & .117 & .408 & -.019 \\
\hline 設問8 & .103 & -.117 & .164 & .628 \\
\hline 設問9 & .155 & -.042 & .164 & -.474 \\
\hline 累積寄与率 & & & & 34.15 \\
\hline
\end{tabular}




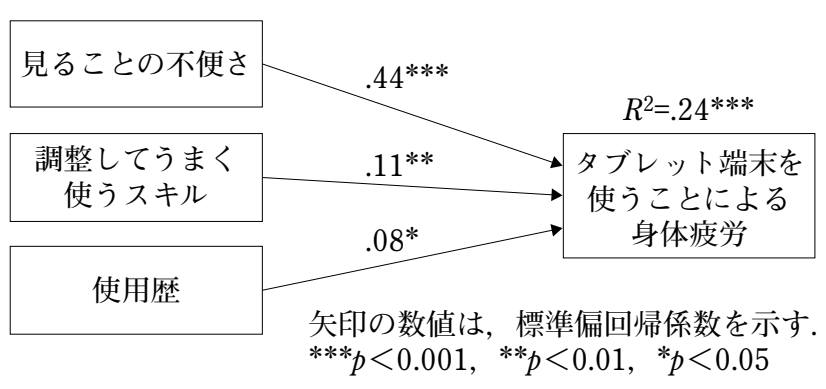

図7 身体疲労に関する重回帰分析の結果

Fig. 7 Result of multiple regression analysis on physical fatigue.

成されて抢り，「画面に入力する方法」と解釈された.

次に，これらの4つの因子と，疲労に関してたずねた 設問15との関連を検討するために，重回帰分析を行った. その際，児童の学年は必ずしもタブレット端末の使用年 数と一致しないことを考慮し, 学校でのタブレット端末 の使用歴を変数として投入することにした．使用歴は， 現在の学年と学校でタブレット端末を使い始めた学年を 基に算出した.

4つの因子の因子得点と学年, 使用歴を独立変数とし, 設問15の回答を従属変数とした重回帰分析（ステップワ イズ法）を行い，決定係数が最も大きいモデルを選択し た $\left(F(3,630)=69.42, p<0.001\right.$; 調整済み $\left.R^{2}=.24\right)$ 。そ の結果, 第2因子 $(\beta=.44, p<0.001)$ と第3因子 $(\beta=.11$, $p<0.01)$, 使用歴 $(\beta=.08, p<0.05)$ が, 設問 15 に関連 していた（図7)。すなわち，身体に疲労を感じる程度に は，見ることに関する不便さが最も関連して打り，次に， タブレット端末を調整してうまく使うこと，そして使用 歴の長さが関連していることが示された。，一方，第1因 子と第4因子は身体の疲労感には関連していなかった。

\section{4-5. 身体疲労の部位}

設問16で回答された，タブレット端末を使った学習 での疲れやこり，痛み，だるさ等があった部位の結果を 図8に示す。グラフは調査対象全体に対する割合を，疲 れの訴え率として示している．また，身体の図において 灰色になっている部分は，訴え率が $5 \%$ 以上の部位であ ることを示している.

最も訴えの多かった疲労部位は眼であり, 約 $23 \%$ の児 童から訴えがあった (図8の6，7番)，次に訴えの多かっ た疲労部位は首と肩であり，それでれ，約 $18 \%$ の児童 から訴えがあった（図8の15，16，17，18番，及び19， 20, 51，52番).

その他の疲労部位として，手首（約 $12 \% ，$ 図8の59, 60 番), 背中 (約 $11 \%$, 図 8 の $21 ， 22 ， 26$ 番) p右手の人 差し指（約7\%，図8のi）に対する訴えも多かった．腰に 対する訴えは児童の約4\%であった (困8の31，32番)。

次に, 疲労の訴えが顕著であった眼, 首, 肩に関して, 4，5，6年生の結果を図9に示す。ここでは，それぞれの 学年に打ける割合を算出したため，学年ごとの特徵を示 している.

眼，首，肩ともに，学年が上がるにつれて訴え率が上 昇して打り，特に眼の疲労の訴えに扎いてその傾向が顕

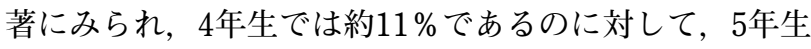
が約 $16 \% ， 6$ 年生が約 $25 \%$ であった。学年による差異を 分析するために，学年と疲労の訴えの有無について $\chi^{2}$ 検 定を行った。その結果，学年によって有意な人数の偏り がみられた $\left(\chi^{2}(2)=14.20, p<0.001, V=0.14\right)$. 残差分 析の結果，4年生は他の学年に比べて眼の疲労を訴えた 児童が少なく $(p<0.01) ， 6$ 年生は他の学年に比べて眼の 疲労を訴えた児童が多かった $(p<0.01)$ 。な打，首に関 しても学年によって有意な人数の偏りがみられ $\left(\chi^{2}(2)=\right.$ 6.31，p<0.05, $V=0.10) ， 6$ 年生において他の学年と比 べて疲労を訴えた児童が多かった $(p<0.05)$ ．肩に関し ても学年によって有意な人数の偏りがみられ $\left(\chi^{2}(2)=\right.$ $8.82, p<0.05, V=0.11), 4$ 年生に打いて他の学年に比 べて疲労を訴えた児童が少なかった $(p<0.01)$.

\section{5. 考 察}

\section{5-1. タブレット端末の使いやすさ}

質問紙調査の結果，半数以上の児童がタブレット端末 の画面に蛍光灯が映りこんで見にくかった経験があり，約 $75 \%$ の児童がタブレット端末の画面に蛍光灯が映りこむこ とを認識していた．視野内における高輝度な光源により， 見えづらさや不快感を生じさせるような矓しさはグレアと 呼ばれ，作業を妨害したり，視覚負担を助長したりするこ とが指摘されている5 。 そのため，映り込みの防止対策が 必要であるが，市販されているタブレット端末の画面は， 反射率の高いガラス面であることが多く，教室の蛍光灯が 画面に鮮明に映り込み，グレアが生じやすい，また，文部 科学省が定める学校環境衛生基準には教室の明るさについ て示されて抢り，教室の照度の下限值は $300 \mathrm{~lx}$ と，教室 及び黒板の照度は $500 \mathrm{~lx}$ 以上であること, そして, コンピュー タを使用する教室等の机上の照度は500 1000 lx程度が望 ましいと記載されている6)。このように，学校の教室は， 学習に適した明るい作業環境となるように指針が決められ ている，そのため，北半球にある日本の学校では，教室の 空は南向きであることが多く，日が差し込みやすい状況に 
ある．明るい教室環境を作ることに加え，教室は元々，タ ブレット端末などのディスプレイを用いることが想定され ていないため, 普通教室には遮光カーテンが取り付けられ ていないこともよくある，また，画面への映り込みを軽減

\section{疲労の訴え率}
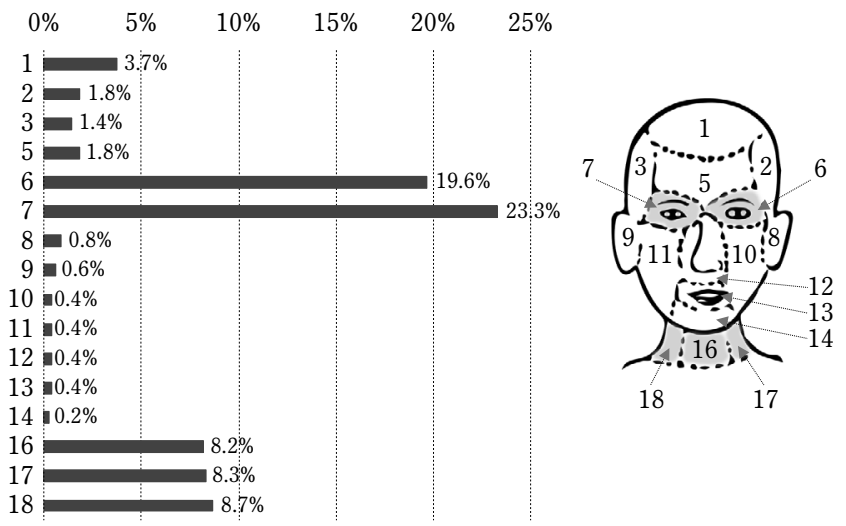

\section{疲労の訴え率}

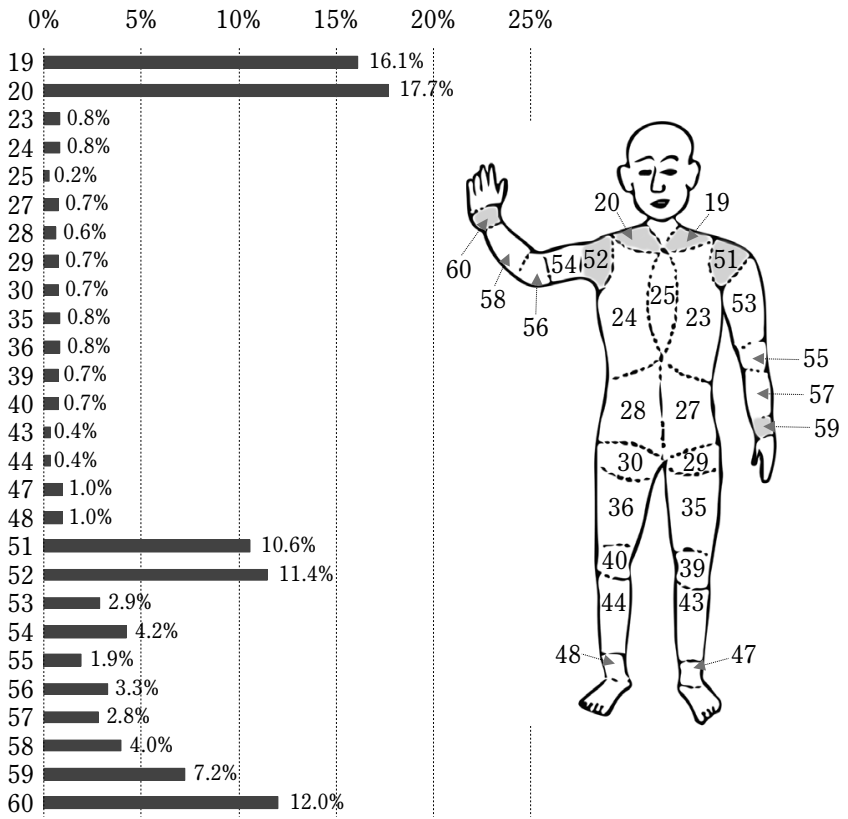

疲労の訴え率

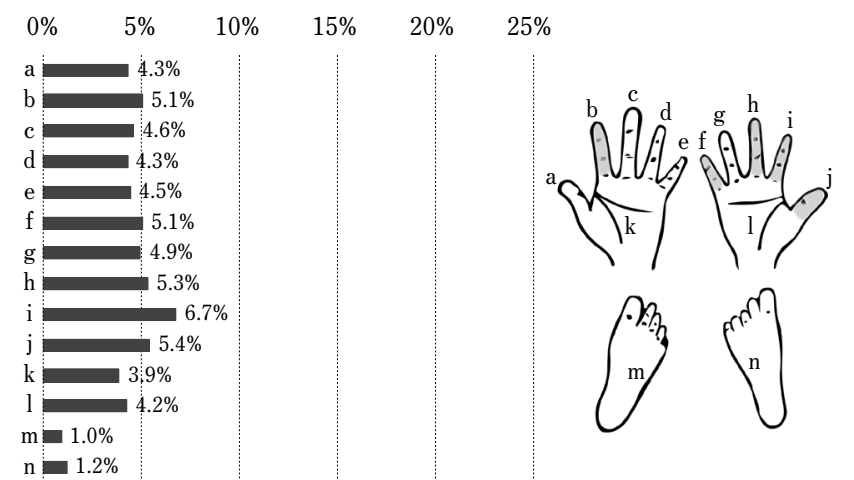

させるルーバーが蛍光灯に付いていることはほとんどない. 学校環境衛生基準には, 背後からの光はコンピュータの画 面に映り込むので，画面上の反射や影が少なくなるように 留意する必要があると書かれているが6)，教室での実際の

疲労の訴え率

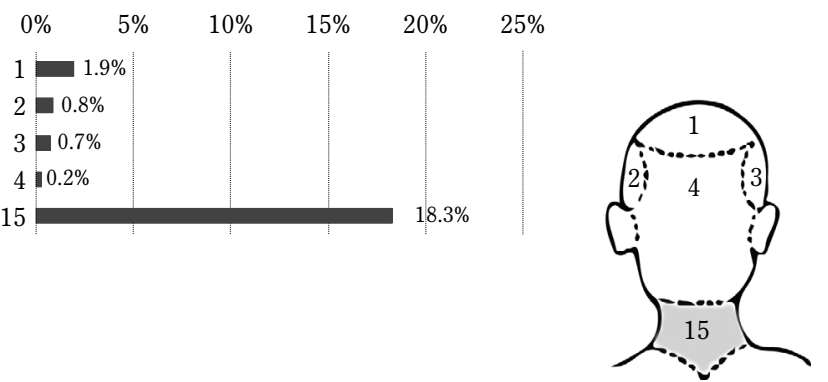

疲労の訴え率

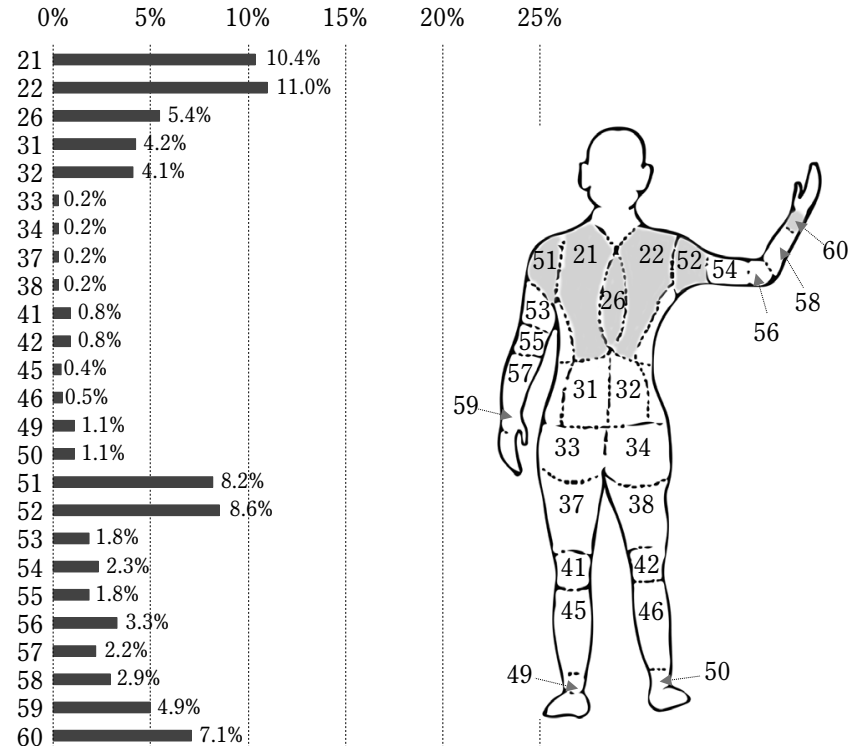

図8 タブレット端末を使うことによる疲労部位の結果（設問16）(日本産業衛生学会による身体疲労部位調査票の図を改变)

Fig. 8 Result of physical fatigue due to tablet use (Question 16). 


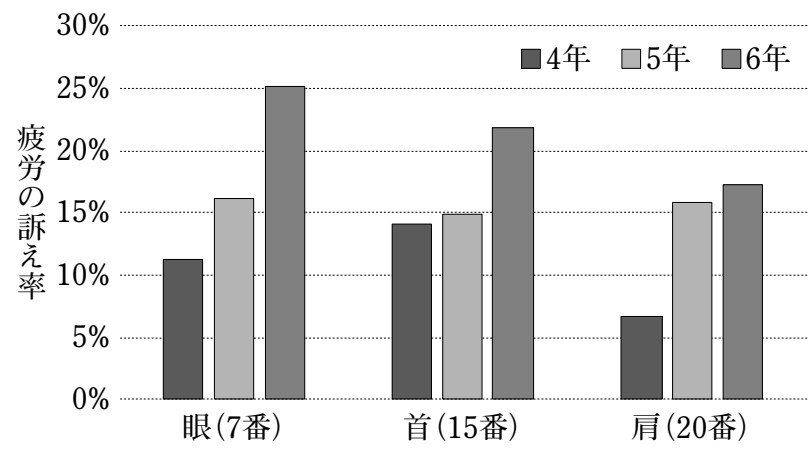

図9 眼，首，肩に打ける疲労の学年比較の結果（設問16）

Fig. 9 Result of grade comparison of fatigue on eyes, neck, and shoulder (Question 16).

利用には十分な対策が必要であると考えられる．さらに， コンピュータの画面に明るい光があたると画面のコントラ ストが下がり，表示されている内容が見にくくなる，その ため，厚生労働省による「VDT作業における労働衛生管 理のためのガイドライン7」では，ディスプレイ画面上に おける照度は500 lx以下にするようにとされている。 また， 学校環境衛生基準では, テレビやコンピュータ等の画面の 垂直面照度は，100～500 lx程度が望ましいとされている6). 教室でのタブレット端末の利用において，画面上における 照度が高くなり過ぎないように配慮することも重要であろう。

VDT（Visual Display Terminals）作業が行われる職場で は，グレア対策が進められたことで，眼の疲れと照明の映 り込みとに関連性がみられなくなり，作業環境の改善がな されている8).ディスプレイの利用場面の拡大に加え, 学 校では発達段階にある子どもが用いるため, 教室環境の改 善あるいはICT機器の改良や対策は極めて重要であろう。

児童によるタブレット端末を使った学習においては, 画面への映り込みがあると視認性が低下し，画面に打け る重要な学習箇所を見落とすなど，学習にネガティブな 影響を与えてしまう可能性がある，また，映り込みを回 避するために，児童は，タブレット端末を動かさずに自 分の身体を動かし，親き込むようにして画面を見ること も予想され，児童の姿勢が悪くなるという懸念もある. そのため, 太陽光や蛍光灯などの光源がタブレット端末 に映り込まないように十分な対策を講じることが必要で ある。ささらに，重回帰分析の結果からも，身体疲労には 見ることに関する不便さが最も関連していたことからも， 視環境の整備は重要であると言える.

晴れた日の教室では，特に午後の時間や冬の時期は， 空から太陽光が差し込むことがあり，タブレット端末へ の映り込みが問題となり得る.しかし，太陽光に対しては， 遮光カーテンや通常のカーテンを使うことで調整するこ
とができるだろう。そのため，蛍光灯による映り込みの 方が，より現実的な問題と考えられる.

蛍光灯の映り込みを防ぎ，画面を見やすくする方法と しては，タブレット端末を傾けるという対策がある．学校 での授業の様子を観察すると，タブレット端末の下に筆箱 や自作の台を挟むことでタブレット端末を傾けて使ってい る様子も実際に見られる，そのため，対策としては実用 的であると言えるかもしれない，しかし，設問5の結果か ら，タブレット端末を傾ける理由としては，画面への映り 込みを回避する目的よりも，正面から画面を見ることで文 字や写真などを見やすくするためであることが示された. それは，画面を傾けることで，児童の視線を画面に直交す る角度に近づけることができ，画面が見やすくなるから であるが，見やすくするためにタブレット端末を傾けた結 果，蛍光灯が映り込んでしまうということも十分に考えら れる. また，タブレット端末の角度と映り込みの有無は， 蛍光灯との位置関係に依存しているため，児童の座席配 置によっても状況が異なる，そのため，タブレット端末を 机の上に置いて使うという教室の利用環境に扎いては，ア ンチグレアフィルムの利用も効果的であると考えられる.

さらに設問5の結果から，タブレット端末を傾ける理 由として，画面をタッチしやすくするためという回答が 2番目に多かった。タブレット端末を少し傾斜させると， タブレットペンでの書きやすさやタッピングのしやすさ が向上するといった報告もある9-11)。そのため，アンケー 卜の設問12に打ける自由記述で多く見られた文字の書き にくさに対しては，タブレット端末を傾斜させることで 改善することが期待できる.

タブレット端末を傾斜させることは，映り込みを防い だり，書きやすさを向上させたりするための良い工夫で あると言える.しかし，人間工学の観点から考えると，ユー ザーである児童に工夫を強いることは好ましくないため, 映り込みを軽減するタブレット端末の開発や，傾斜させ るためのチルト機能を備えたタブレット端末の開発など が必要であろう。

設問6からは，約半数の児童が，画面の文字が小さく て見にくいので表示を大きくする経験があることが示さ れたが，拡大縮小ができることはタブレット端末でデジ タル教科書・教材を用いる利点でもある。それは，細か くて見づらい文字などを大きくして見やすくできるから である．従来の紙メディアの場合には，姿勢を崩して眼 を近づけることで対応していたかもしれないため，健康 面への悪影響を軽減させるためにも，タブレット端末で の拡大縮小機能について，児童生徒にしっかりと教える べきことであろう。さらに，拡大縮小の操作は，画面上 
で複数の指を用いてピンチイン・ピンチアウトをするため, 画面上での指の滑りやすさについての検討や配慮も必要 かもしれない，例えば，指が滑りにくく使いづらい場合， 操作性が低下するだけでなく，児童生徒は拡大操作を諦 め，眼を近づけたり，学習上重要な筒所を適切に見られ なかったりしてしまうかもしれない.

設問7の結果からは，約61\%の児童が画面の明るさを 自分で調整したことが全くなかったが，それはタブレッ 卜端末の明るさが自動調整されていることが理由として 考えられた。

\section{5-2. 身体疲労について}

タブレット端末の利用において，児童の 3 人に 1 人が， 眼や首，肩などに身体的疲労を感じていることが結果か ら明らかになった。 また，半数以上の児童が，タブレッ 卜端末を使うときの方が，紙の教科書を使うときよりも 目が疲れると思っていた． ICT機器を用いたときのみに 疲労が生じ, 従来の紙メディアによる学習法では疲労が 生じないということではないが，タブレット端末を利用 したときの方が，主観的な疲労感が高いことが考えられ る. 疲労の原因としては，タブレット端末の利用では, 画面の見やすさの維持や映り込みの回避のために姿勢が 拘束されることが考えられる。また，紙とは異なり，タ ブレット端末自体が光を発していることや表示画像や文 字の解像度が低いことが問題であるかもしれない，本調 查の結果からは原因を特定できないため, 今後, 詳細に 検討していく必要がある.

設問16での疲労部位調査では，両眼に対する訴えが顕 著に多かったが，視覚疲労が生じる原因の一つとして， 調節性眼精疲労が考えられる，すなわち，近くのものを 長時間見続けることによる調節機能の低下による疲労で ある．設問13の結果より，約3割の児童が，タブレット 端末を使うときは，紙の教科書を使うときよりも目を近 づけていると自覚していることが示されたが，実際の利 用状況と疲労の程度との関係性を探ることが今後の課題 として挙げられる.

これまで，デジタルデバイスのユーザーは成人である ことが多く，そのため，身体疲労に関する評価も成人を 対象とすることが多かった。 しかし，ICT機器を児童生 徒が使うようになった現在，子どもの身体疲労について も詳細に検討していく必要がある. 本研究による調査結 果に基づけば，学年を問わず，小学 1 年生も身体疲労の 訴えがあった。 また近年，ICT機器利用による子どもの 疲労や筋骨格系疾患に関する報告もいくつかなされてい る ${ }^{12,13)}$. 子どもの発達段階などとも考え合わせて多角的
に検討していく必要もあるであろう.

文部科学省が 2018 年3月に公表した「平成29年度学校保 健統計調査」によると，小学生の裸眼視力が 1.0 未満の児 童が $32.46 \%$ であり，それは1979年の調查開始以来，最も 高い数值であった ${ }^{14)}$. 近くを見る機会や時間が増えること が，近視が進行する一つの要因とも考えられているため， タブレット端末の利用により，近視進行が助長されないよ うに配慮することが必要である．また，強度の近視はその 他の眼の疾患に進行する可能性があるため ${ }^{15)}$ ，近視の進行 予防という視点からも十分に配慮することが重要である.

また，裸眼視力が 1.0 未満の子どもの割合は，中学校で は $56.33 \%$ ，高等学校では $62.30 \%$ と高くなる ${ }^{14)}$. さらに， 学童期に打ける近視の割合は年齢とともに高くなり，特 に10〜12歳にかけての変化が大きいことも報告されてい る16). 本調查に打ける視覚疲労の訴えを小学 $4 ， 5 ， 6$ 年生 で比較した結果でも，学年が上がるにつれて訴え率が高く なっていたが（眓9），近見作業の増加に因るものである可 能性が考えられ，近視の進行との関係性を示唆するもので あるかもしれない，そのため，子どもの近視進行を䂆防す るという観点からも，学校でのタブレット端末の利用方法 に関して, 今後の詳細な検討と対応が必要であると考える.

タブレット端末を利用する際，画面が見えにくいこと を回避するためや，紙の教科書やノートなども置かれて いて机の上が狭いなどの理由により，児童生徒の姿勢が 悪くなることもある．また，机と椅子の高さが合ってい ないことで，姿勢が悪くなってしまっていることも考え られる，そのため，教室での正しい姿勢の指導とともに， 学習規律を徹底することで，児童生徒の身体の負担の軽 減につながると考えられる.

また，正しい鉛筆の持ち方の指導をするのと同様に， 正しいタブレットペンの持ち方や文字の書き方にも注意 を払うことが重要であると考えられる。

児童生徒の健康面への影響は，保護者や教師も心配す る重要課題であるため ${ }^{17)}$ ，懸念される項目やそれらの影 響の程度などを検討していくことが必要である．健康面 で心配されることを十分に検討し，安全なICT学習環境 を整備することが必要である。

\section{6. おわりに}

本研究では，小学校でタブレット端末を 1 年以上使用 した児童830名を対象として，タブレット端末の使いや すさと児童の身体的側面への影響に関するアンケート調 查を実施した。

本研究の結果より, 安全で快適なICT学習環境の実現 
に向け，ICT機器のポジティブな側面のみならず，使い にくさや問題点などといったネガティブな側面も明確に し，それらの解決を図っていく必要性が示唆された．また， 学校でのタブレット端末の利用は，学習場面に応じて， 手で持ったり，机に水平に置いたり，立てて使ったりと 様々である. そのため, 今後はタブレット端末の使用状 態に着目した検討も必要であろう。児童生徒が安全で快 適にICTを利用できる学習環境を整えることで，ICTを 活用した学習を支援することができると考えられる.

\section{謝 辞}

本研究の実施にあたり，ご協力いただいた小学校の教 員及び児童の皆様に，感謝の意を表す.

\section{文 献}

1）文部科学省. 平成 29 年度学校における教育の情報化の 実態等に関する調査結果. http://www.mext.go.jp/a_menu/ shotou/zyouhou/detail/1408157.htm, (参照 2019-08-27).

2）文部科学省. 学びのイノベーション事業. http://www.mext. go.jp/a_menu/shotou/zyouhou/detail/1408183.htm, (参照 2019-08-27)

3）文部科学省. 児童生徒の健康に留意して ICTを活用 するためのガイドブック. 2014, http://www.mext.go.jp/ component/a_menu/education/micro_detail/__icsFiles/ afieldfile/2018/08/14/1408183_5.pdf, (参照 2019-08-27).

4）大島正光, 大久保克夫. 人間工学, 東京, 朝倉書店, 1989, p.70.

5) Hultgren, G.V.; Knave, B. Discomfort glare and disturbances from light reflections in an office landscape with CRT display terminals. Applied Ergonomics. 1974, 5 (1) , p.2-8. doi: 10.1016/0003-6870 (74) 90251-8.

6) 文部科学省. 学校環境衛生管理マニュアル「学校環境衛 生基準」の理論と実践 [平成30年度改訂版]. 2018, http:// www.mext.go.jp/component/a_menu/education/detail/ __icsFiles/afieldfile/2018/07/31/1292465_01.pdf（参照 2019-08-27).

7）厚生労働省. VDT作業における労衝衛生管理のためのガ イドラインについて. 2002, https://www.mhlw.go.jp/file/ 06-Seisakujouhou-11200000-Roudoukijunkyoku/ 0000184703.pdf (参照 2019-08-27).

8）岩切一幸, 毛利一平, 他. VDT作業者の身体的疲労感 に影響する諸因子の検討. 産業衛生学雑誌. 2004, 46 (6), p.201-212. doi: 10.1539/sangyoeisei.46.201.

9) Albin, T.J.; McLoone, H.E. The effect of tablet tilt angle on users' preferences, postures, and performance. Work. 2014, 47 (2) , p.207-211. doi: 10.3233/WOR-131670.

10) Bao, D.; Xin, Y.; et al. "Effect of tilt angle of tablet on pen-based input operation based on Fitts' law". IEEE: Proceedings of the IEEE International Conference on Information and Automation. Harbin, China, 2010-06-
20/23, p.99-104. doi: 10.1109/ICINFA.2010.5512344

11) Shibata, T. "Effects of tablet tilt angle on children's handwriting in elementary school". International Ergonomics Association: Proceedings of 19th Triennial Congress of the IEA. Melbourne, Australia, 2015-08-09/14.

12) Ciccarelli, M.; Fraser, K. "Children's utilisation of allied health treatment to manage ICT-related pain”. International Ergonomics Association: Proceedings of 19th Triennial Congress of the IEA. Melbourne, Australia, 2015-08-09/14.

13) Jacobs, K.; Baker, N. The association between children's computer use and musculoskeletal discomfort. Work. 2002, $18(3)$, p. $221-226$.

14）文部科学省. 学校保健統計調査一平成 29 年度 (確定值) の 結果の概要. 2018, http://www.mext.go.jp/b_menu/toukei/ chousa05/hoken/kekka/k_detail/1399280.htm，（参照 2019-08-27).

15）川崎良, 大野京子. 増加する近視 ·強度近視. 医学の歩み. 2015, 253 (2), p.159-161.

16) Matsumura, H.; Hirai, H. Prevalence of myopia and refractive changes in students from 3 to 17 years of age. Survey of Ophthalmology. 1999, 44 (1), p.109-115. doi: 10.1016/S0039-6257 (99) 00094-6.

17）柴田隆史, 藤井彌智, 他. “学校でのICT導入に対する生 徒と保護者の健康面に関する意識”。 日本人間工学会関東 支部第48回講演集. 2018, p.86-87.

\section{著者情報}

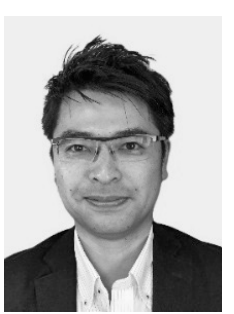

柴田隆史（しばたたかし，正会員，連絡著者） 2004年早稲田大学大学院国際情報通信研 究科博士後期課程満期退学. 博士 (国際 情報通信学)。日本学術振興会特別研究員 $\mathrm{PD} ，$ カリフォルニア大学バークレー校ポ ストドクトラルフェロー等を経て，2018 年より東京福祉大学教育学部教授。専門領 域 : 人間工学，視覚工学. 日本人間工学会 子どものICT活用委員会委員長ほか.

連絡先：tashibat@ed.tokyo-fukushi.ac.jp

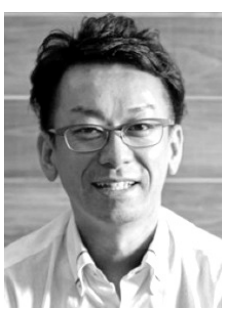

佐藤和紀（さとうかずのり）

2018年東北大学大学院情報科学研究科博 士後期課程修了. 博士（情報科学)。東京 都公立小学校教諭を経て，2017年より常 葉大学教育学部初等教育課程専任講師。専 門領域 : 教育工学, 特に学校現場の情報化. 日本教育工学会会員，日本教育工学協会理 事ほか.

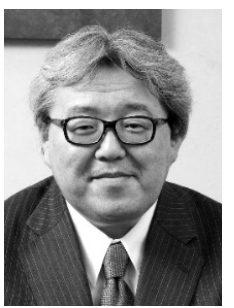

\section{堀田龍也（ほりたたつや）}

2009年東京工業大学大学院社会理工学研 究科博士後期課程修了。博士 (工学)。東 京都公立小学校教諭，文部科学省参与等の 勤務を経て，2014年より東北大学大学院 情報科学研究科教授. 専門領域: 教育工学, 特に学校現場の情報化. 日本教育工学会副 会長ほか. 